Tạp chí Các Khoa học về Trái Đất, 38 (1), 38-45

$\begin{array}{r}\text { Viện Hàn lâm Khoa học và Công nghệ Việt Nam } \\ \text { Tạp chí Các Khoa học về Trái Đất } \\ \text { Website: http://www.vjs.ac.vn/index.php/jse } \\ \hline\end{array}$

\title{
Hệ thống kiến trúc kiến tạo và đặc điểm địa động lực khu vực Tây Bắc trong giai đoạn Kainozoi muộn
}

\author{
Nguyễn Văn Hùng*1', Hoàng Quang Vinh ${ }^{1}$, Nguyễn Văn Hướng ${ }^{2}$ \\ ${ }^{I}$ Viện Địa chất, Viện Hàn lâm Khoa học và Công nghệ Việt Nam \\ ${ }^{2}$ Truờng Đại học Khoa học Tự nhiên, Đại học Quốc gia Hà Nội
}

Chấp nhận đăng: 10 - 2 - 2016

ABSTRACT

Tectono-structural system and geodynamic features of Northwest Vietnam in the late Cenozoic period

Occurrences of the Late Cenozoic tectonic activities in Northwest Vietnam are clear and relatively complete by the combination of specific tectono-structural features. The most significant feature is represented by the NW-SE oriented right-lateral extensional movement strongly occurred in the entire geoblock along the SW margin of Red River fault zone. This geoblock is in fact a transextensional megablock, comprising entire NW Viet Nam and part of Yunnan province of China. Located between Indochina and South China blocks this geoblock shows the most active character in term of high relief differentiation and strong seismicity as compared with other nearby regions.

C2016 Vietnam Academy of Science and Technology

\section{Mở đầu}

Hệ thống kiến trúc vùng Tây Bắc và cao hơn thế là đặc điểm địa động lực trong giai đoạn Kainozoi muộn không chỉ có giá trị trong phân tích đánh giá điều kiện địa chất kiến tạo của khu vực này mà còn có ý nghĩa thực tế rất lớn trong nghiên cứu tai biến tự nhiên lãnh thổ. Có rất nhiều kết quả nghiên cứu xung quanh vấn đề này đã được công bố. Tuy nhiên, về toàn bộ hệ thống kiến trúc Kainozoi muộn của vùng cũng như những đặc điểm cơ bản về địa động lực khu vực được phản ánh qua hệ thống này vẫn chưa được đề cập đến. Do đó những kết quả nghiên cứu qua nhiều năm của các tác giả được được tổng hợp trong bài viết này nhằm nêu lên những nhận thức đầy đủ hơn về bối cảnh kiến tạo - địa động lực khu vực, cũng như làm cơ sở cho việc đánh giá chính xác các hiện tương tai biến địa chất liên quan và xa hơn là góp

*Tác giả liên hệ, Email: hqvinh1886@yahoo.com phần giải quyết những tồn tại trong nghiên cứu chuyển động kiến tạo của khu vực.

\section{Hệ thống kiến trúc kiến tạo Kainozoi muộn}

Trên cơ sở phân tích các tài liệu về kiến tạo vật lý, địa chất - địa mạo, kiến trúc - kiến tạo của Tây Bắc, Tân kiến tạo và bối cảnh địa động lực Kainozoi cũng như chuyển động hiện đại của khu vực Bắc Việt Nam (Trần Đình Tô, Nguyễn Trọng Yêm, 1991; Nguyễn Trọng Yêm, 1996), có tính đến lịch sử phát triển của vùng với hai pha kiến tạo thay thế kế tiếp nhau trong Kainozoi (Nguyễn Trọng Yêm, 1998; Nguyễn Văn Hùng 2002),... toàn bộ hệ thống kiến trúc Kainozoi muộn khu vực Tây Bắc đã được xác định, bao gồm các đới đứt gãy và các đới kiến trúc với những đặc điểm rất đặc thù.

\subsection{Các đới đứt gãy kiến tạo}

Nếu các đới đứt gãy nằm trên ranh giới giữa các mảng kiến tạo là bậc I thì hệ thống đứt gãy 
N.V. Hùng và nnk/Tạp chí Các Khoa học về Trái Đất, Tập 38 (2016)

lãnh thổ Tây Bắc, chủ yếu, gồm đới đứt gãy bậc II Sông Hồng, đới dứt gãy bậc III phương AKT: Lai Châu - Điện Biên cùng với các đới đứt gãy bậc IV

phương TB-ĐN và cao hơn (Nguyễn Trọng Yêm và nnk 1998; Nguyễn Văn Hùng 2002). Phần lớn trong số chúng đều trượt bằng thuận là chủ yếu (hình 1).

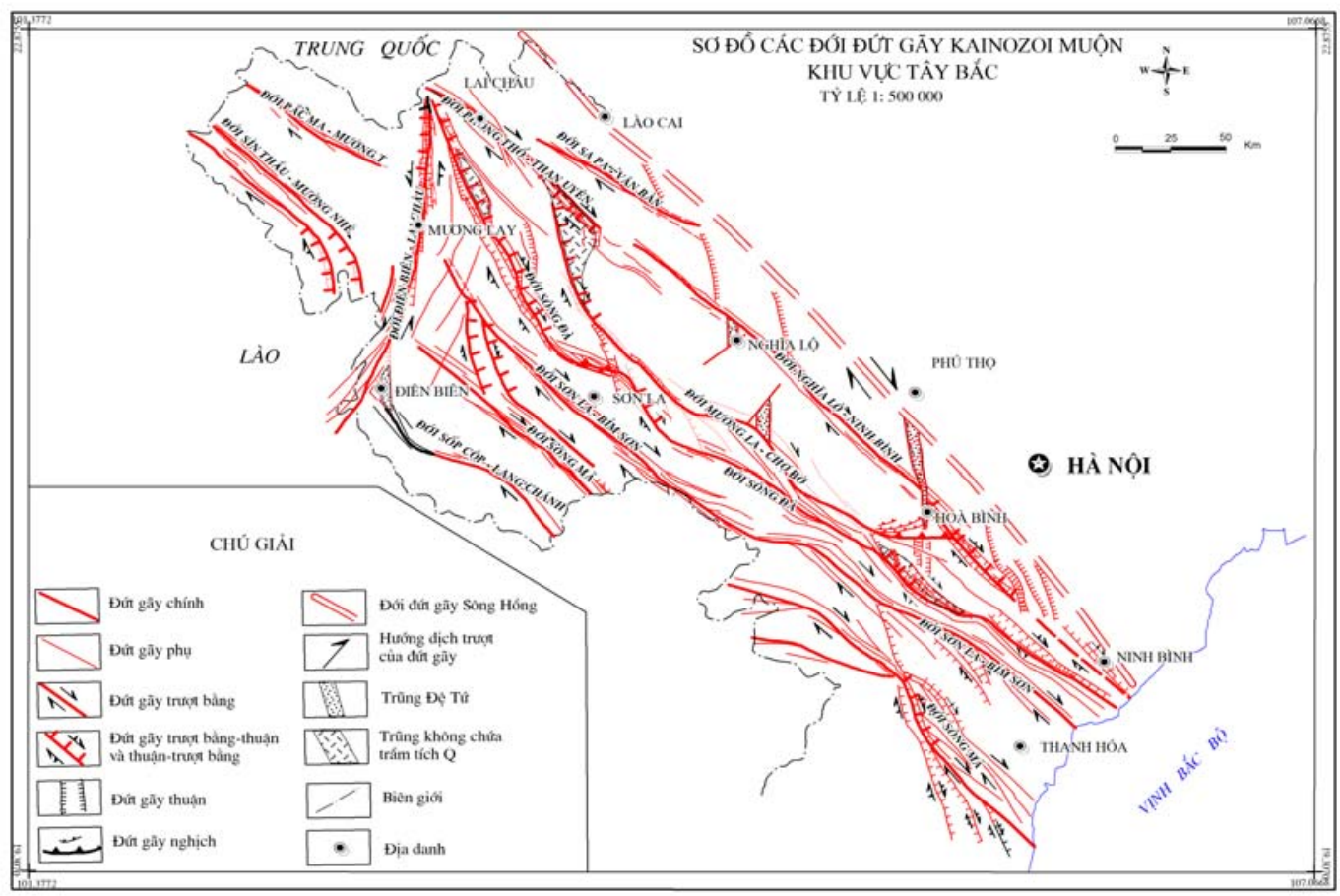

Hình 1. Sơ đồ các đới đứt gãy Kainozoi muộn khu vực Tây Bắc

- Đới đứt gãy Sông Hồng (bậc II) (hình 1) có lịch sử hoạt động lâu dài. Trong Kainozoi muộn, đới này (phần trên lãnh thổ Việt $\mathrm{Nam}$ ) chủ yếu chuyển dịch trượt bằng phải đi kèm với thành phần thuận do hạ lún cánh đông bắc. Theo các tài liệu địa chất - địa mạo cũng như các số liệu trắc địa, chuyển dịch ngang phải dọc đứt gãy Sông Hồng trong giai đoạn Đệ tứ có tốc độ trung bình 4,5$5 \mathrm{~mm} / \mathrm{năm}$. Ngoài ra, còn có sự sụt lún chung của cánh đông bắc so với cánh tây nam với tốc độ khoảng $2 \mathrm{~mm} /$ năm (Nguyễn Trọng Yêm và nnk 1998, Trần Trọng Huệ, nnk, 2004).

Về phía đông nam thành phần thuận của đới càng lớn và chiếm ưu thế hoàn toàn trong trũng Sông Hồng, với biên độ sụt lún trong Kainozoi đạt $5-6 \mathrm{~km}$ ở trũng Hà Nội và trên $14 \mathrm{~km}$ ở ngoài khơi vịnh Bắc Bộ (Nguyễn Trọng Yêm và nnk, 1998; Nguyễn Mạnh Huyền, Hồ Đắc Hoài 2005).
- Đới đứt gãy Lai Châu - Điện Biên (bâc III) (hình 1) là nhánh nhỏ phía đông bắc của đới đứt gãy Luông Pha Băng - Pursat (kéo dài đến tận gần vịnh Thái Lan) có chiều sâu phát triển đến trên $60 \mathrm{~km}$. Mặt trượt của đới nghiêng dốc đứng khoảng $>80^{\circ}$ về phía tây. Hoạt động của đới trong Kainozoi muộn có lẽ được bắt đầu từ trước Pliocen, thời điểm xuất hiện các phun trào bazan ở trũng Điện Biên vào 5,8 triệu năm trước (Nguyễn Hoàng và nnk, 1996) và còn tiếp tục đến ngày nay. Chuyển động của đới chủ yếu là tách giãn - trượt bằng trái. Hoạt động trượt bằng và tách giãn trong Đệ tứ của đới Điện Biên - Lai Châu đã tạo nên các trũng Đệ tứ ở Pà Tần, Chăn Nưa, Mường Lay, Mường Phồn, Điện Biên Phủ; khúc uốn ngoặt về phía bắc với biên độ khoảng $800 \mathrm{~m}$ của dòng sông Đà ở thị xã Mường Lay và biến dạng của hàng loạt các suối nhánh cắt ngang qua đới đứt gãy (Nguyễn Trọng Yêm và nnk 1998; Nguyễn Văn Hùng 2002). 
Tạp chí Các Khoa học về Trái Đất, 38 (1), 38-45

- Các đới đứt gãy bậc IV gồm một loạt các đới đứt gãy phương TB-ĐN.

+ Đới Pắc Ma - Mường Tè và đới Sìn Thầu Mường Nhé đều có phương TB-ĐN (hình 1), bắt đầu từ sâu trong lãnh thổ Trung Quốc Phần trên lãnh thổ Việt Nam, đới đứt gãy Pắc $\mathrm{Ma}$ - Mường Tè dài khoảng $90 \mathrm{~km}$, đới đứt gãy Sìn Thầu Mường Nhé khoảng $120 \mathrm{~km}$. Tính chất chủ yếu của hai đới đứt gãy này là trượt bằng phải trong Kainozoi muộn (riêng đới Sìn Thầu - Mường Nhé có phần trượt thuận ở đầu đông nam). Biên độ trượt bằng phải của đới Pắc $\mathrm{Ma}$ - Mường Tè là khoảng 1000-1350m. Tốc độ có thể đạt 0,2 $1 \mathrm{~mm} / \mathrm{n}$. Biên độ trượt bằng phải của đới Sìn Thầu - Mường Nhé đạt từ 2800 đến $5000 \mathrm{~m}$, tốc độ (tính tròn 6tr.n) sẽ vào khoảng $0,4-0,8 \mathrm{~mm} / \mathrm{n}$ (Nguyễn Văn Hùng, 2002).

+ Đới đứt gãy Phong Thổ - Than Uyên dài hơn $100 \mathrm{~km}$ từ Nậm Cúm, đến Than Uyên. Đới phát triển đến độ sâu $35-40 \mathrm{~km}$. Trong Kainozoi muộn đới vừa trượt bằng phải vừa trượt thuận. Biên độ bằng phải là $1300-1800 \mathrm{~m}$, tốc độ dịch chuyển khỏang $0,23-0,3 \mathrm{~mm} / \mathrm{n}$ (trong Pliocen-Đệ tứ) (Nguyễn Văn Hùng 2002).

+ Đới đứt gãy Mường La - Chợ Bờ dài hơn $250 \mathrm{~km}$, (hình 1 ), trượt bằng phải trong Kainozoi muộn với biên độ từ $800 \mathrm{~m}$ đến $2000 \mathrm{~m}$ trong Pliocen - Đệ Tứ, tốc độ dịch chuyển có thể đạt 0,1 $0,5 \mathrm{~mm} / \mathrm{n}$ (Nguyễn Trọng Yêm và nnk 1998).

+ Đới đứt gãy Sông Đà sâu 35-40km, dài $450 \mathrm{~km}$ từ Pà Tần (Phong Thổ) đến bờ biển Kim Sơn (Ninh Bình) (hình 1). Đới trượt bằng phải thuận trong Kainozoi muộn với biên độ ngang trong Đệ tứ $1-2,5 \mathrm{~km}$, biên độ đứng trong khoảng 400- $00 \mathrm{~m}$ tại một số nơi với cánh đông bắc hạ tương đối (Nguyễn Trọng Yêm và nnk 1998).

+ Đới đứt gãy Sơn La-Bỉm Sơn kéo dài $360 \mathrm{~km}$ từ Nậm Nèn (Mường Lay) đến bờ biển Nga Sơn (Thanh Hóa) (hình 1), sâu tới mức bazan, nghiêng $60-80^{\circ}$ về đông bắc. Trong giai đoạn Kainozoi muộn đới đứt gãy trượt bằng phải (có hợp phần thuận ở đầu đông nam), biên độ khoảng 10001500m (Nguyễn Văn Hùng, 2002; Trần Trọng Huệ, nnk, 2004).

+ Đới đứt gãy Sông Mã dài gần $400 \mathrm{~km}$ từ Mường Ảng (Điện Biên) đến bờ biển Tĩnh Gia
(Thanh Hóa) (hình 1). Đới đứt gãy Sông Mã chủ yếu là trượt bằng phải thuận trong Kainozoi muộn, biên độ trượt bằng phải của đới khoảng 1200$1400 \mathrm{~m}$, tốc độ trong Pliocen-Đệ tứ đạt từ 0,15 đến 0,3mm/n (Nguyễn Văn Hùng 2002).

+ Đới Sốp Cộp - Lang Chánh kéo dài hơn $250 \mathrm{~km}$ từ Điện Biên chạy qua Sốp Cộp sang Lào rồi qua khu vực $\mathrm{Na}$ Mèo vào Việt Nam gặp đới Sông Mã ở Lang Chánh (hình 1). Trong Kainozoi muộn đới đứt gãy Sốp Cộp - Lang Chánh trượt bằng phải là chủ yếu. Biên độ của các đứt gãy khoảng 1200-1800m (Nguyễn Văn Hùng 2002).

- Các đới đứt gãy bậc cao: bao gồm các đới đứt gãy phương TB-ĐN như: Sa Pa - Văn Bàn, Nghĩa Lộ-Ninh Bình có chiều dài $50-60$ đến trên $100 \mathrm{~km}$ và các đới của trũng Hoà Bình dài trên $40 \mathrm{~km}$ có phương AKT (Nguyễn Trọng Yêm và nnk 1998) (hình 1).

\subsection{Hệ thống kiến trúc Kainozoi muộn khu vục Tây Bắc}

Hầu hết các đới, khối kiến trúc của pha hoạt động kiến tạo muộn nhất (Kainozoi muộn) ở Tây Bắc (hình 2) được thành tạo trên cơ sở kế thừa về hình thái và cấu tạo từ các đá của các kiến trúc trước đó. Nhưng chúng đã được biển đổi mạnh mẽ do đã bị lôi cuốn vào các vận động kiến tạo trong pha này (Trần Đình Tô, Nguyễn Trọng Yêm, 1991; Nguyễn Văn Hùng và nnk, 2013), tạo nên hệ thống kiến trúc mới, thống nhất, hoàn toàn phù hợp và phản ánh rất rõ đặc điểm trường ứng xuất kiến tạo Kainozoi muộn - Hiện đại và đặc điểm địa động lực giai đoạn này tại Tây Bắc (Nguyễn Trọng Yêm, 1996; Nguyễn Trọng Yêm, Gusenko O..I., Lê Minh Quốc, Mostrikov A., 1996; Nguyễn Văn Hùng và nnk, 2013). Hệ thống này gồm một loạt các đới kiến trúc (dương, âm) và các kiến trúc bậc cao (Nguyễn Văn Hùng và nnk, 2014).

\subsubsection{Các đới kiến trúc duơng}

Thuộc rìa phía bắc có đới kiến trúc bị nâng mạnh trong Kainozoi muộn (Trần Đình Tô, Nguyễn Trọng Yêm 1991) Hoàng Liên Sơn (hình 2). Đới Hoàng Liên Sơn là đới kiến trúc dương kế thừa, phát triển trên các đá biến chất, với phần nhân là khối granit Kainozoi Yalsun. 
N.V. Hùng và nnk/Tạp chí Các Khoa học về Trái Đất, Tập 38 (2016)

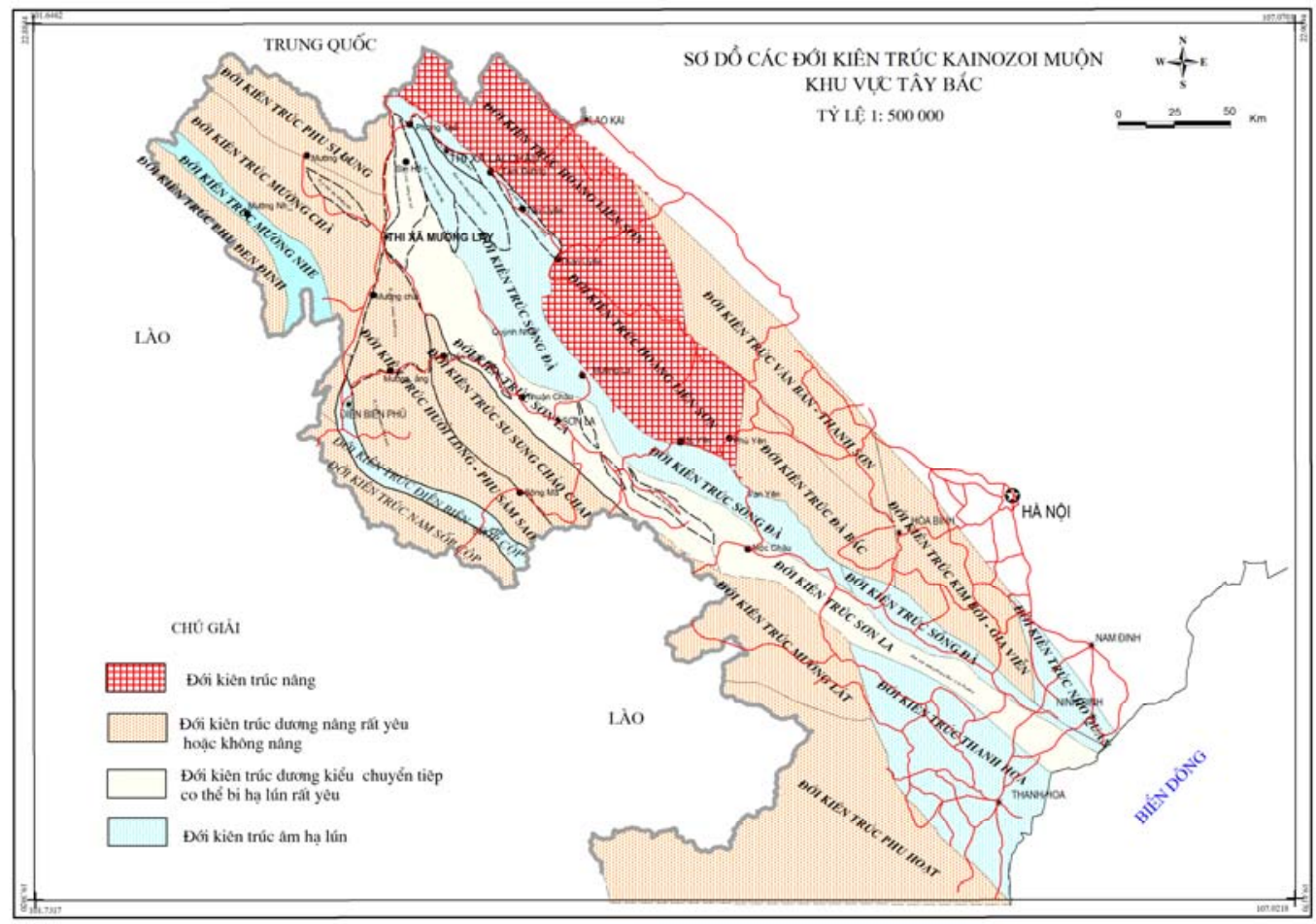

Hình 2. Sơ đồ các đới kiến trúc Kainozoi muộn khu vực Tây Bắc

Tiếp đến là các đới kiến trúc dương có thể không bị nâng lên hoặc nâng không đáng kể trong Kainozoi muộn (Trần Đình Tô, Nguyễn Trọng Yêm 1991, Nguyễn Văn Hùng và nnk, 2013):

- Đới Phu Si Lung có dạng tuyến, phân bố ở phía tây bắc Lai Châu (hình 2) phát triển trên các thành tạo Paleozoi, bị lôi cuốn vào hoạt động tạo núi nâng mạnh trong Kainozoi sớm và ổn định (?) trong Kainozoi muộn.

- Đới Văn Bàn - Thanh Sơn kéo dài theo rìa tây nam của đứt gãy Sông Hồng (hình 2). Đới cấu tạo từ các đá trầm tích biến chất có tuối khác nhau từ Tiền Cambri đến Paleozoi.

- Đới Đà Bắc (hình 2) cấu tạo chủ yếu từ các đá biến chất Tiền Cambri (Trần Trọng Huệ và nnk, 2004). Kiến trúc thể hiện là tập hợp các dãy núi với độ cao trung bình $600-1000 \mathrm{~m}$, thấp dần từ tây nam đến đông bắc.

- Đới Kim Bôi - Gia Viễn: nằm ở phía đông nam vùng nghiên cứu, phát triển trên kiến trúc cổ - đới Ninh Bình (Lê Duy Bách, Ngô Gia Thắng
1996). Trong giai đoạn Kainozoi muộn, kiến trúc này chìm dần về phía đông nam.

- Đới Mường Chà phát triển trên các thành tạo tuổi $\mathrm{Pz}-\mathrm{Mz}$, nằm giữa các đới đứt gãy Pác $\mathrm{Ma}$ Mường Tè, Sìn Thầu - Mường Nhé và Lai Châu Điện Biên.

- Đới Phu Đen Đinh: là kiến trúc phát triển kế thừa từ kiến trúc cổ thuộc đới Phong Xa Lỳ được cố kết vào thời kỳ Mezozoi muộn với thành phần chủ yếu là đá trầm tích molas lục địa.

- Đới Su Sung Chảo Chai: nằm kẹp giữa đứt gãy chính Sơn La - Bỉm Sơn và đới đứt gãy Sông Mã. Đới cấu thành từ các đá Tiền Cambri, thể hiện trên địa hình là dãy núi đồ sộ cùng tên với độ cao trung bình $1000-1500 \mathrm{~m}$, kéo dài theo phương TB-ĐN.

- Đới Huổi Long - Phu Săm Sao bị giới hạn bởi các đới đứt gãy Sơn La - Bỉm Sơn, Bản Búng, Sông Mã, Điện Biên - Lai Châu, Sốp Cộp - Lang Chánh (hình 2). Đới nằm trong đới kiến trúc cổ được cố kết vào đầu Paleozoi giữa. Đới gồm một số kiến trúc bậc cao (Nguyễn Văn Hùng và nnk, 
Tạp chí Các Khoa học về Trái Đất, 38 (1), 38-45

2013), các kiến trúc thể hiện là các dãy núi trên địa hình với độ cao trung bình 1000-1500m.

- Đới Nam Sốp Cộp thuộc “mảnh” kiến trúc Sầm Nưa - Phu Hoạt (Nguyễ் Văn Hùng 2002), phát triển trên võng Sầm Nưa cổ. Trên địa hình, đới kiến trúc thể hiện là tổ hợp các dãy núi cao trung bình $800-1500 \mathrm{~m}$.

- Đới Mường Lát nằm kẹp giữa đới đứt gãy Sơn La - Bỉm Sơn và đới đứt gãy Sốp Cộp - Lang Chánh. Phía đông là 1 đứt gãy phương AKT. Đới nằm trên một phức nếp lồi cổ được cố kết vào đầu Paleozoi. Trên địa hình đó là dãy núi cao trung bình $1200-1500 \mathrm{~m}$ thấp dần về phía đông nam.

- Đới Phu Hoạt là một phần của "mảnh" Sầm Nưa - Phu Hoạt (Nguyễn Văn Hùng 2002; Nguyễn Văn Hùng và nnk, 2014), có dạng vòm đẳng thước có độ cao $1500-1600 \mathrm{~m}$ ở đầu tây đến $2000 \mathrm{~m}$ tại Bù Khạng sau đó thấp dần về phía biển (hình 2). Đới Phu Hoạt có phân nhân là khối granit lớn bao quanh là các thành tạo tuổi Paleozoi, Mezozoi.

Kéo dài dọc theo phần trung tâm, Đới Sơn La là đới kiến trúc chuyến tiếp giữa các đới kiến trúc dương phía tây nam với đới sụt lún Sông Đà phía đông bắc. Đới Sơn La tạo thành một dải lớn kéo dài từ tây bắc xuống đông nam, nằm giữa hai đới đứt gãy lớn: Sông Đà và Sơn La - Bỉm Sơn. Đới nằm chủ yếu trên một phần kiến trúc cổ Võng Sông Đà đã được cố kết vào Mezozoi. Trên địa hình, đới thể hiện là dải sơn nguyên và cao nguyên đá vôi, cao từ trên $1000 \mathrm{~m}$ (Sìn Hồ) đến gần $1000 \mathrm{~m}$ (Tủa Chùa); 600-700m (Mai Sơn); 900m (Mộc Châu và dãy núi Thung Khe - Cúc Phương (từ $900 \mathrm{~m}$ thấp xuống 200-300m) kéo dài ra tận bờ biển Ninh Bình (hình 2). Đới này cũng gồm một loạt các kiến trúc bậc cao (Nguyễn Văn Hùng và nnk 2013, 2014).

\subsubsection{Các đới kiến trúc âm}

Các đới kiến trúc âm đều nằm kẹp giữa các đới dương và có xu thế sụt lún so với hai bên.

- Đới Mường Nhé được ngăn cách bởi đứt gãy Sìn Thầu - Mường Nhé ở phía đông bắc và một đứt gãy nhánh của nó ở phía tây nam. Phía tây bắc đới kéo dài sang lãnh thổ Trung Quốc (hình 2). Đới có dạng tuyến, nằm trong đới kiến trúc cổ Mường Nhé được cố kết vào thời kỳ Mezozoi (Nguyễn Văn Hùng và nnk, 2013).

- Đới Sông Đà bị khống chế bởi đới đứt gãy Phong Thổ - Than Uyên nối tiếp với đới đứt gãy Mường La - Chợ Bờ ở phía đông bắc và đới đứt gãy Sông Đà ở phía tây nam (hình 2). Đới Sông Đà có dạng tuyến kéo dài gần $400 \mathrm{~km}$, được hình thành trên một phần của Võng Sông Đà cồ. Trong đới sông đà còn phát triển hàng loạt các kiến trúc bậc cao (Nguyễn Văn Hùng và nnk, 2013; 2014).

- Đới Điện Biên - Sốp Cộp kéo dài từ Mường Phồn qua Điện Biên, Sốp Cộp đến biên giới Lào. Đới được phân bố trong phạm vi đới đứt gãy Sốp Cộp - Lang Chánh với ranh giới hai bên đông bắc và tây nam là các đứt gãy hợp phần của đới đứt gãy này. Đới Điện Biên - Sốp Cộp phát triển trên nền móng các thành tạo Mezozoi. Trong Tân kiến tạo, đới kiến trúc này chuyển từ chế độ xiết trượt (ở Kainozoi sớm) sang chế độ giãn trượt sụt lún (ở pha sau - Kainozoi muộn).

- Đới Thanh Hóa nằm giữa đới đứt gãy Sơn La - Bỉm Sơn ở phía đông bắc và đới đứt gãy Sông Mã ở phía tây nam, đứt gãy AKT Bá Thước-Ngọc Lạc ở phía tây và Trũng Sông Hồng ở phía đông. Đới phát triển trên nền móng của đới Thanh Hóa cổ (Lê Duy Bách, Ngô Gia Thắng, 1996), bị lôi kéo vào quá trình sụt lún trong Kainozoi muộn. Phần móng bị phá hủy rất mạnh, gồm các thành tạo có tuổi từ Cambri cho đến Mezozoi còn lộ rõ tại rất nhiều nơi. Lớp phủ trầm tích Đệ Tứ của đới có chiều dày không lớn (Nguyễn Văn Hùng và nnk, 2014).

\subsubsection{Bối cảnh địa động lực Kainozoi muộn khu vục Tây Bắc}

Trên cơ sở phân tích đặc điểm hệ thống đứt gãy và các đới kiến trúc Kainozoi muộn trên đây, có thể hình dung ra những nét chính về bức tranh hoạt động kiến tạo - địa động lực khu vực Tây Bắc trong giai đoạn này như sau:

- Dọc theo tất cả các đới đứt gãy lớn trượt bằng và trượt bằng thuận đã xẩy ra rất mãnh liệt và là phông chung của vùng Tây Bắc trong giai đoạn này (Nguyễn Văn Hùng, 2002). Ở vùng Lai Châu Mường Tè đới đứt gãy Lai Châu - Điện Biên trượt bằng trái thuận dẫn đến việc hình thành một loạt trũng kéo tách (kiểu $P$ ) và tách giãn (kiểu $G$ ) dọc theo đới đứt gãy. Các đới đứt gãy Pắc $\mathrm{Ma}-$ Mường Tè, Sìn Thầu - Mường Nhé trượt bằng phải khá mạnh. Riêng tại phần đông nam của đới Sìn Thầu Mường Nhé các đứt gãy chuyển thành vòng cung $\mathrm{AKT}$, trượt thuận, góp phần tạo nên các thung lũng lòng chảo và các bề mặt rộng thấp cùng phương tại đó. 


\section{N.V. Hùng và nnk/Tạp chí Các Khoa học về Trái Đất, Tập 38 (2016)}

Về phía đông đới đứt gãy Lai Châu - Điện Biên, có thể thấy hoạt động của các đới đứt gãy có sự khác biệt chút ít giữa các khu vực. Tại phần tây bắc, ở khu vực Điện Biên - Tuần Giáo - Lai Châu Phong Thổ - Than Uyên, nơi phổ biến các nhánh, đoạn đới đứt gãy có phương $\mathrm{BTB}-\mathrm{NĐN}$ và $\mathrm{AKT}$, có chế độ trượt bằng với tách giãn cục bộ, phân dị mạnh. Đới đứt gãy Phong Thồ - Than Uyên; phần tây bắc các đới đứt gãy Mường La - Chợ Bờ, Sông Đà trượt bằng phải thuận. Còn tại các đới Sơn $\mathrm{La}$ Bỉm Sơn, Sông Mã chủ yếu là trượt bằng phải với các nhánh phụ, các đứt gãy vòng cung AKT ở khu vực Tủa Chùa - Tuần Giáo - Điện Biên thể hiện rõ tính chất trượt thuận và tách giãn. Trong khu vực này còn thấy những dấu hiệu hình thành một số kiến trúc kiểu $\mathrm{P}$ có kích thước tương đối lớn dọc các đới đứt gãy như tại: Ma Quai - Nậm Mạ, Bình Lư - Than Uyên (Nguyễn Văn Hùng 2002, Nguyễn Văn Hùng và nnk, 2013).

Khu vực còn lại, phần đông nam tồn tại một chế độ kiến tạo trượt bằng kết hợp với tách giãn nhưng tương đối điều hoà với xu thế càng về phía đông nam thành phần thuận càng tăng. Tại các đới đứt gãy lớn: Nghĩa Lộ - Ninh Bình, Mường La Chợ Bờ, Sông Đà, Sơn La - Bỉm Sơn thuộc phạm vi các tỉnh Yên Bái, Sơn La và tây bắc tỉnh Hoà Bình, trượt bằng phải chiếm vai trò chủ đạo. Ở phần cuối đông nam của các đới đứt gãy lớn, đã xuất hiện một loạt đứt gãy trượt bằng thuận đi đôi với việc thành tạo các trũng dạng địa hào. Dọc đới Nghĩa Lộ - Ninh Bình biểu hiện của tính chất trượt bằng phải - thuận thể hiện rất rõ từ Hòa Bình về phía đông nam. Phần đông nam của đới đứt gãy Sông Đà đã xuất hiện trũng giữa núi Tân Lạc Nho Quan. Phần đông nam của các đới Sơn La Bỉm Sơn và đới Sông Mã quá trình trượt bằng thuận thể hiện khá rõ nét ở quá trình hạ lún kiến tạo tại đới sụt lún Thanh Hóa (Nguyễn Văn Hùng và nnk, 2014).

Đồng thời với hoạt động của các đới đứt gãy (ranh giới của các đới kiến trúc), vận động của hệ thống các đới kiến trúc khu vực Tây Bắc trong giai đoạn này cũng nổi lên những nét chính phản ánh mhững vận động kiến tạo - địa động lực chung ở đây. Mặc dù toàn bộ hệ thống các đới khối kiến trúc đều kế thừa những kiến trúc được hình thành trước đó về hình thái và cấu tạo. Do đó, quá trình chuyển động và biến dạng trong giai đoạn Kainozoi muộn của chúng là rất phức tạp. Tuy nhiên, vẫn có thể hình dung được những nét chính về quá trình dịch trượt, trồi sụt do vận động trượt ngang và căng giãn giữa chúng gây nên:

- Các đới kiến trúc dương nằm ở hai rìa tây bắc (Hoàng Liên Sơn) và rìa đông nam (mảnh Sầm Nưa - Phu Hoạt) có lẽ vừa trượt bằng phải tương đối vừa được dồn vào hướng trung tâm theo phương bắc nam từ địa khối Indosini ở phía nam và từ khối Hoa Nam ở phía bắc trong trường ứng suất chung có phương nén ép AKT.

- Hệ thống các đới kiến trúc (nằm khoảng giữa chúng) bị dịch trượt tương đối với nhau dọc theo các đới đứt gãy và tham gia vào quá trình phân dị thẳng dứng để tạo nên hệ thống các đới kiến trúc dương và âm như đã được mô tả.

- Ở nửa phần tây bắc ngoài đới được nâng lên Hoàng Liên Sơn, các đới kiến trúc dương còn lại có thể không bị nâng lên trong giai đoạn này như Mường Chà, Huối Long - Phu Sam Sao, Su Sung Chảo Chai, Phu Sam Cap,... Còn các đới kiến trúc âm nằm giữa chúng đều là những kiến trúc sụt dạng tuyến được tạo nên theo cớ chế “ trượt giãn" nên nhỏ, hẹp, kéo dài và hầu như không có trầm tích dày.

- Ở nửa phần đông nam cũng với cơ chế tương tự nhưng do ảnh hưởng tách giãn từ bồn Sông Hồng nên các đới kiến trúc dương đều bị hạ hấp độ cao, còn các kiến trúc âm bị sụt nhiều hơn và lớp phủ trầm tích cũng dày hơn.

Có thể thấy toàn bộ hệ thống kiến trúc (các đới đứt gãy và các đới kiến trúc) Kainozoi muộn Tây Bắc hoạt động rất đồng bộ và gắn kết mật thiết với nhau thể hiện một phông kiến tạo - địa động lực chung. Trên thực tế chúng đều thuộc về một đơn vị kiến trúc lớn hơn có dạng hình thoi dài, chại dọc theo rìa tây nam đới đứt gãy sâu Sông Hồng từ Vân Nam Trung Quốc đến tận bờ biển Việt Nam (hình 3). Hình hài của nó, nhìn chung, phản ánh rất rõ đặc điểm biến dạng kiến tạo chung là trượt bằng phải chủ đạo kết hợp với tách giãn. Điều này hoàn toàn phù hợp với những biến dạng của tổ hợp các kiến trúc hợp thành (chủ yếu phương kéo dài TBĐN), mà vùng Tây Bắc Việt Nam là đại diện, nằm bên trong nó. Điều này đồng nghĩa với việc những hoạt động kiến tạo - địa động lực (đã tạo nên một tổ hợp các kiến trúc đặc thù) ở vùng Tây Bắc Việt Nam chính là biến dạng kiến tạo bên trong một kiến trúc lớn hơn trùm lên nó. 
Tạp chí Các Khoa học về Trái Đất, 38 (1), 38-45

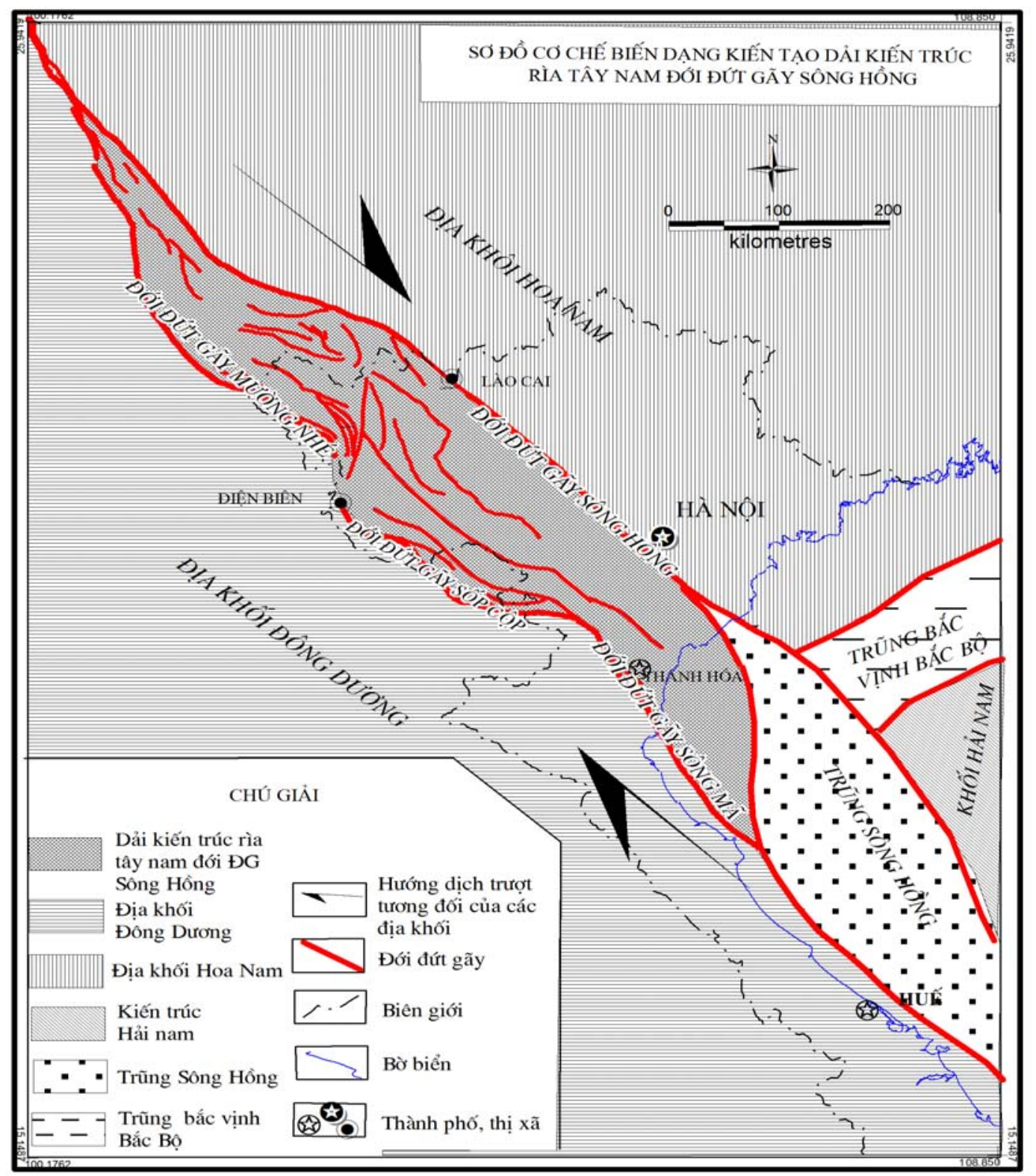

Hình 3. Sơ đồ cơ chế biến dạng kiến tạo Kainozoi muộn dải kiến trúc rìa tây nam đới đứt gãy Sông Hồng,

Vị trí kiến tạo và bối cảnh địa động lực Kainozoi muộn của vùng Tây Bắc trên đây cho thấy vùng này (thuộc rìa động đông bắc của địa khối Đông Dương) là miền tương tác của địa khối này với khối Hoa Nam. Do vậy mà ở đây hoạt tính kiến tạo - địa chấn cao khác thường như đã được biết đến (Nguyễn Đình Xuyên và nnk, 1997; Nguyễn Trọng Yêm và nnk, 1998).
Ngoài ra, những biến dạng kiến tạo Kainozoi muộn tại đây còn cho thây rõ điạ khôi Đông Dương đang trượt tương đối (về phía tây bắc) so với khối Hoa Nam (trượt về phía đông nam) tạo ra một trường trượt bằng thuận phải trên toàn dải tương tác. Hoạt động này chỉ có thể xảy ra trong trường ứng xuất kiến tạo chung kiểu trượt bằng (có thành phần thuận), với phương trục nén ép AKT 


\section{N.V. Hùng và nnk/Tạp chí Các Khoa học về Trái Đất, Tập 38 (2016)}

(Nguyễn Trọng Yêm, 1996; Nguyễn Trọng Yêm và nnk, 1996) của khu vực.

Hơn thế, với vị trí đặc biệt, là miền tương tác của của địa khối Đông Dương với khối Hoa Nam, bối cảnh địa động lực Kainozoi muộn vùng Tây Bắc còn phản ánh những tương tác theo hướng bắc nam giữa mảng Châu Úc và lục địa Âu - Á tại khu vực này.

\section{Kết luận}

Những phân tích trên đây cho phép đưa một số kết luận sau:

Hệ thống đứt gãy kiến tạo Kainozoi muộn khu vực Tây Bắc gồm đới đứt gãy bậc II Sông Hồng, các đới đứt gãy bậc IV phương TB-ĐN có chiều dài hàng trăm kilomet đều trượt bằng phải và phải thuận, đới đứt gãy bậc III Lai Châu - Điện Biên dài hơn $100 \mathrm{~km}$ trượt bằng trái thuận và các đứt gãy bậc cao trượt bằng hoặc trượt thuận.

Hệ thống các đới kiến trúc đều có dạng tuyến gồm các đới kiến trúc dương và âm kéo dài cũng theo phương TB-ĐN và xen kẽ luân phiên nhau thấp dần theo hướng từ $\mathrm{DB}$ và $\mathrm{TN}$ vào trung tâm (về võng Sông Đà). Các kiến trúc này vừa trượt ngang tương đối với nhau vừa nâng hạ trồi sựt phân dị phức tạp nhưng trên bình diện chung vẫn thể hiện rất rõ tính chất trượt bằng phải của toàn vùng.

Toàn bộ hệ thống kiến trúc kiến tạo của vùng Tây Bắc đểu nằm trong dải kiến trúc rìa tây nam đới đứt gãy Sông Hồng có hình thái của một kiến trúc "trượt giãn" lớn kéo dài từ Vân Nam Trung Quốc ra đến tận bờ biển Việt Nam, phản ánh điều kiện địa động lực chung của toàn bộ dải nói chung và của vùng Tây Bắc Việt Nam nói riêng là trượt bằng phải kết hợp với tách giãn thuận phân dị.

Đặc điểm địa động lực chung của vùng Tây Bắc Việt Nam cũng như toàn bộ dải kiền trúc rìa nam đới đứt gãy Sông Hồng trên đây phản ánh rất rõ tính chất trượt phải tương đối của hai địa khối Indosini và Hoa Nam. Sự dịch trượt này trùm lên toàn bộ phần đông bắc cũng như phần tây nam đới đứt gãy Sông Hồng trong Kainozoi muộn.... Xa hơn hoạt động kiến tạo - địa động lực được thể hiện qua hệ thống kiến trúc Kainozoi muộn vùng Tây Bắc có thể còn là biểu hiện của sự xồ húc từ mảng Châu Úc vào Đông Nam Á

\section{Tài liệu dẫn}

Lê Duy Bách, Ngô Gia Thắng, 1996: Phân vùng kiến tạo Tây
Bắc Việt Nam. Địa chất KS, 5, tr.96-105.

Nguyễn Hoàng, Phạm Tích Xuân và nnk, 1996: Vấn đề động lực hình thành magma basalt Kainozoi Việt Nam qua kết quả nghiên cứu thành phần nguyên tố vết và đồng vị. Địa chất tài nguyên, 1, tr.156-166.

Trần Trọng Huệ và nnk, 2004: Nghiên cứu đánh giá tổng hợp các loại hình tai biến địa chất trên lãnh thổ Việt Nam và các giải pháp phòng tránh (giai đoạn II - Các tỉnh miền núi phía Bắc) Đề tài độc lập cấp Nhà Nước. Lưu trữ Viện Địa chất, Viện HLKH\&CN Việt Nam, Hà Nội.

Nguyễn Văn Hùng, 2002: Những dặc điểm cơ bản đứt gãy tân kiến tạo Tây Bắc Việt Nam. Luận án TS Địa chất,Thư viện Quốc Gia, Hà Nội.

Nguyễn Văn Hùng và nnk, 2013: Nghiên cứu đánh giá phân vùng dự báo hiện tượng tai biến trượt lở - nứt sụt đất, lũ quét - lũ bùn đá khu vực Sơn La - Lai Châu, đề xuất các giải pháp phòng tránh giảm nhẹ thiệt hai. Đề tài cấp Viện Hàn Lâm. Lưu trữ Trung tâm Thông tin tư liệu, Viện HLKH\&CN Việt Nam, Hà Nội.

Nguyễn Văn Hùng và nnk, 2014: Mối quan hệ của hoạt động kiến tạo Kainozoi muộn với tai biến địa chất khu vực Tây Bắc. Báo cáo đề tài cơ sở. Lưu trữ Viện Địa chất - Viện HLKH\&CN Việt Nam, Hà Nội.

Nguyễn Mạnh Huyền, Hồ Đắc Hoài 2005: Bể trầm tích Sông Hồng và tài nguyên dầu khí. Tạp Chí Địa chất và tài nguyên dầu khí Việt Nam, tr.179-235

Trần Đình Tô, Nguyễn Trọng Yêm, 1991: Chuyển động thẳng đứng lãnh thổ miền Bắc Việt Nam theo các số liệu do lặp thủy chuẩn chính xác. Tc. Địa chất số 202-203, Hà Nội.

Nguyễn Đình Xuyên, 1989: Phân vùng động đất lãnh thổ Việt Nam. Tc. Các Khoa học về Trái Đất, T.11, 3-4, tr.40-50.

Nguyễn Đình Xuyên và nnk, 1997: Tính động đất và độ nguy hiểm động đất trên lãnh thổ Việt Nam. Thành tựu nghiên cứu vật lý địa cầu 1987-1997, tr.34-91.

Nguyễn Trọng Yêm, 1996: Phân vùng trường ứng suất kiến tạo hiện đại lãnh thổ Việt Nam. Địa chất tài nguyên, 1, tr.8-13.

Nguyễn Trọng Yêm, 1996: Trường ứng suất kiến tạo Kainozoi lãnh thổ Việt Nam. Tạp chí Các khoa học về Trái đất, T.18, 3CĐ, tr.193-197.

Nguyễn Trọng Yêm, Gusenko O..I., Lê Minh Quốc, Mostrikov A., 1996: Trường ứng suất hiện đại và cơ thức biến dạng vỏ Trái đất Đông Nam Á. Địa chất tài nguyên, II, tr.8-13.

Nguyễn Trọng Yêm và nnk, 1998: Nghiên cứu thiên tai nứt đất lãnh thổ Việt Nam. Đề tài độc lập cấp Nhà nước 19941998. Lưu trữ Viện Địa chất, Viện KH\&CN Việt Nam, Hà Nội. 